\title{
ANALISIS SIFAT FISIK DAGING SAPI TERDAMPAK LAMA PERENDAMAN DAN KONSENTRASI KENIKIR (Cosmos caudatus kunth)
}

\author{
Rohmah, Mohammad Fuad Fauzul Mu’tamar *, Umi Purwandari \\ Teknologi Industri Pertanian, Universitas Trunojoyo Madura \\ Penulis korespondensi: mohammadfuadfm@ trunojoyo.ac.id
}

\begin{abstract}
Beef is one of the most popular food commodities. Beef often has textural problems, especially when consumed. One method to improve the tenderness of beef is by enzymatic treatment. In some plants there are meat-eating enzymes. This study aims to determine the influence of leaves kenikir (cosmos caudatus kunth) against the tenderness of beef. The researchers used a complete randomized RAL design method with two factors each of the 3 levels of the first factor of leaf extract of kenikir with 25, 50, 75\% concentration while the second factor was the immersion time of 15, 30 and 45 minutes. The test parameters included hardness, cooking shrinkage, power water tie and sensory (aroma, color, texture). The results showed that the texture test decreased the level of hardness of beef along with the increased concentration of the added leaves. Likewise with the long immersion, the longer the soaking results of the hardness of beef being tried further decreased.
\end{abstract}

Keywords: Kenikir (Cosmos Caudatus kunth), Beef

\section{PENDAHULUAN}

Daging sapi merupakan komoditas pangan dengan kandungan gizi tinggi. Kandungan air rata rata $77.65 \%$, kadar lemak rata rata $14.7 \%$ dan kadar protein rata rata $18.26 \%$ (prasetyo et al, 2013). Daging olahan memiliki kandungan protein dan air lebih sedikit dan lebih banyak mengandung lemak dan mineral (Soeparno 2005). Daging sapi umumnya digunakan sebagai salah satu menu dalam makanan, baik sebagai daging secara murni atau dibuat dalam bentuk berbagai macam olahan, mulai dari sate, rawon, gulai, sosis dan lain sebagainya. Permassalahan yang umum dihadapi dalam proses pemasakan daging adalah tekstur yang keras daging sapi kalau tidak diberi perlakuan terlebih dahulu.

Beberapa alternative perlakuan untuk mengempukkan daging diantaranya adalah pemberian enzim papain atau bisa juga dengan enzim bromelin yang masingmasing zat ini terkandung dalam tanaman pepaya dan nanas. Kedua enzim tersebut dapat mengubah atau merombak protein menjadi lebih sederhana sehingga protein yang terdapat di daging sapi terhidrolisis mengakibatkan daging sapi menjadi empuk. Salah satu tanaman diyakini mengandung enzim protease yaitu kenikir (cosmos caudatus). Kenikir merupakan tanaman yang mudah tumbuh di daerah tropis seperti iklim yang terdapat di Indonesia. Tanaman ini mengandung beberapa senyawa sperti aktif seperti flavonoid, polivenol, saponin, tanin, alkaloid dan minyak atsiri dengan berbagai manfaat. (Dwiyanti et al. 2014).

Penelitian ini adalah untuk melihat dan menganalisis pengaruh konsentrasi daun kenikir dan lama perendaman terhadap tekstural daging sapi.

\section{METODE}

Metode penelitian dengan menggunakan rancangan acak lengkap RAL dua faktor dengan masing-masing tiga level faktor pertama ekstrak daun 
kenikir sebanyak 25, 50, dan 50\% dan faktor kedua adalah lama perendaman selama 15, 30 dan 45 menit. setiap sampel dilakukan pengulangan sebanyak 2 (dua) kali. Pengujian dilakukan terhadap beberapa parameter yaitu tingkat kekerasan daging sapi, daya ikat air, dan susut masak. Pengujian tingkat kekerasan dengan menggunakan tekstur analyser TA $X T$. Perhitungan daya ikat air menurut Soerparno (2005) menggunakan water holding capacity (WHC) adalah suatu metode yang digunakan untuk menghitung kemampuan daging untuk mengikat air yang di tambahkan selama ada perlakuan dari luar. Penghitungan daya ikat air menggunakan rumus berikut:

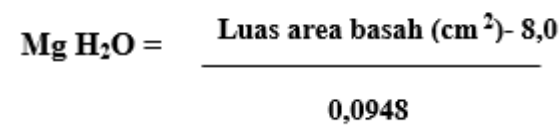

Sedangkan susut masak menurut merupakan berat yang hilang selama pemasakan. Perhitungan susut masak mengikuti rumus berikut:

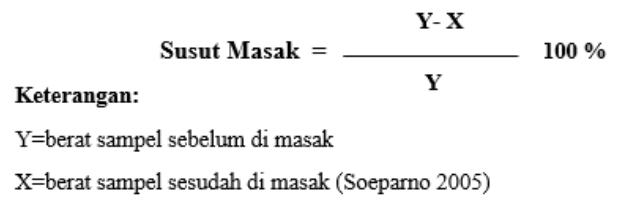

HASIL DAN PEMBAHASAN

Tingkat kekerasan daging sapi (hardness)

Hasil pengujian menunjukkan bahwa semakin meningkatnya konsentrasi kenikir yang ditambahkan kedalam air rendaman akan semakin menurunkan kekerasan daging sapi yang dicobakan. Hasil pengamatan tingkat kekerasan daging sapi ditunjukkan pada Tabel 1.

Tabel 1. Pengaruh Ektrak Kenikir Terhadap Hardness Daging Sapi

\begin{tabular}{cc}
\hline Konsentrasi_kenikir (\%) & Rata-rata $(\mathrm{g})$ \\
\hline 75 & 611,58 \\
50 & 618,15 \\
25 & 625,01 \\
\hline
\end{tabular}

Penurunan tingkat kekerasan daging sapi walaupun tidak signifikan secara statistic, namun jika dilihat dari data pengamatan yang dilakukan menunjukkan terjadi penurunan tingkat kekerasan daging sapi. Hal ini diduga daun kenikir mempunyai senyawa atau enzim yang mampu menghidrolisis protein yang ada didalam daging sapi sehingga daging sapi menjadi empuk. Menurut Fuzzati et al (1995) kenikir mengandung saponin, flavonoid, polifenol, dan minyak atsiri.

Lama perendaman memberikan pengaruh positif terhadap tingkat keempukan daging. Semakin lama direndam, berdampak pada penurunan tingkat kekerasan daging sapi. Lama perendaman 45 menit menunjukkan tingkat kekerasan daging sapi sebesar 594, 21 gf, sedangkan lama perendaman selama 15 menit menunjukkan nilai sebesar 636,79 gf. Hal ini menunjukkan terjadinya penurunan tingkat kekerasan yang dialami daging sapi selama proses perlakuan perendaman. Selengkapnya ditunjukka pada Tabel 2.

Tabel 2. Pengaruh Lama Perendaman Terhadap Tekstur Daging Sapi

\begin{tabular}{cr}
\hline $\begin{array}{l}\text { Lama_perendaman } \\
\text { (menit) }\end{array}$ & Rata-rata (g) \\
\hline 45 & 594,21 \\
30 & 623,74 \\
15 & 636,79 \\
\hline
\end{tabular}

\section{Daya Ikat Air}

Menurut Risnajati (2010) daya ikat air atau WHC diartikan sebagai kemampuan daging untuk menahan air yang terdapat dalam jaringan. Besar kecilnya daya ikat akan mempengaruhi beberapa peristiwa terhadap daging yaitu: warna, keempukan, kekenyalan, juicines dan tekstur daging. Pengaruh lama perendaman dan konsentrasi kenikir ditunjukkan pada Tabel 3 dan Tabel 4. 
Tabel 3. Pengaruh konsentrai kenikir terhadap daya ikat air daging sapi

\begin{tabular}{cl}
\hline Konsentrasi_kenikir(\%) & Rata-rata \\
\hline 75 & $44,50^{\mathrm{a}}$ \\
50 & $131,67^{\mathrm{b}}$ \\
25 & $136,33^{\mathrm{b}}$ \\
\hline
\end{tabular}

Pada tabel 3 menunjukkan bahwa rata-rata nilai daya ikat air karena pengaruh konsentrasi kenikir, nilai tertinggi pada konsentrasi $25 \%$ kenikir yaitu 136,33 sedangkan nilai terendah terdapat pada konsentrasi $75 \%$ kenikir sebesar 44.5. hal ini dapat dikatakan semakin banyak penambahan ekstrak kenikir dapat menurunkan daya mengikat air pada daging sapi. Ekstrak kenikir yang mengandung enzim protease yang dapat mengakibatkan struktur protein terdenaturasi sehingga kemampuan protein mengikat air berkurang.

Tabel 4. Menunjukkan bahwa lama perendaman selama 45 menit berdampak daya ikat air daging menjadi $87 \%$ sedangkan lama perendaman 15 menit daya ikat airnya $126 \%$. Semakin lama perendaman, menunjukkan semakin terjadi proses hidrolisis protein oleh enzim protease dalam air.

Tabel 4. Pengaruh lama perendaman pada daya ikat air daging sapi

\begin{tabular}{cc}
\hline $\begin{array}{l}\text { Lama perendaman } \\
\text { (menit) }\end{array}$ & Rata-rata \\
\hline 45 & $87,00^{\mathrm{a}}$ \\
30 & $99,50^{\mathrm{a}}$ \\
15 & $126,00^{\mathrm{b}}$ \\
\hline
\end{tabular}

\section{Susut masak}

Menurut Khasrad (2010) faktor yang mempengaruhi susut masak daging ada beberapa yaitu status kontraksi miofibril, dan serabut otot. Serabut otot yang pendek meningkatkan susut masak daging sapi. Semakin tua usia sapi akan semakin menurunkan susut masak. Pengaruh lama perendaman dan konsentrasi kenikir ditunjukkan pada Tabel 5 dan Tabel 6 .
Tabel 5. Pengaruh lama perendaman pada susut masak daging sapi

\begin{tabular}{cr}
\hline $\begin{array}{l}\text { Lama_perendaman } \\
\text { (menit) }\end{array}$ & Rata-rata(g) \\
\hline 15 & $37,50^{\mathrm{a}}$ \\
30 & $40,02^{\mathrm{b}}$ \\
45 & $41,81^{\mathrm{c}}$ \\
\hline
\end{tabular}

Tabel 5. Menunjukkan bahwa semakin lama perendaman akan meningkatkan susut masak daging sapi. Hal ini menunjukkan bahwa semakin lama tingkat denaturasi protein akan semakin meningkatkan susut masak daging sapi. Hal ini juga terjadi akibat pengaruh konsentrasi kenikir yang diberikan. Semakin tinggi konsentrasi kenikir, semakin meningkat susut masak daging yang dicobakan.

Tabel 6. Pengaruh ekstrak daun kenikir pada susut masak daging sapi

\begin{tabular}{cc}
$\begin{array}{l}\text { Konsentrasi_kenikir } \\
(\%)\end{array}$ & $\begin{array}{l}\text { Persentase } \\
\text { masak }(\%)\end{array}$ \\
\hline 25 & $38,32^{\mathrm{a}}$ \\
50 & $38,91^{\mathrm{a}}$ \\
75 & $42,10^{\mathrm{b}}$ \\
\hline
\end{tabular}

\section{KESIMPULAN}

Hasil penelitian dapat disimpulkan bahwa perlakuan pemberian ekstrak kenikir pada air rendaman memberikan dampak penurunan tingkat kekerasan daging sapi, sedangkan lama perendaman memberi dampak semakin lama perendaman akan semakin menurunkan tingkat kekerasan daging sapi. Selain itu pemberian perlakuan lama perendaman dan ektrak daun kenikir berdampak pada daya ikat air dan susut masak daging sapi yang dicobakan.

\section{DAFTAR PUSTAKA}

Dwiyanti. W.. Ibrahim. M.. dan Trimulyono. G. 2014. Pengaruh ekstrak daun kenikir (cosmo caudatus) terhadap pertumbuhan 
bakteri bacillus cereus secara in vitro. jurnal biologi. 2(1) : 2-3.

Fuzzati, N., Sutarjadi, Dyatmiko, W., Rahman, A., and Hostettmann, K., 1995, Phenylpropane derivatives from roots of Cosmos caudatus, Phytochemistry, 39(2) hal: 409-412

Khasrad. 2010. Keempukan Daya Mengikat Air dan Cooking Loss Daging Sapi Pesisir Hasil Penggemukan. Seminar Nasional Teknologi Peternakan Dan Veteriner. Fakultas Peternakan Universitas Andalas. Padang.

Prasetyo,H. Masdiana Ch Padaga, Manik Eirry Sawitri. 2013. Kajian Kualitas Fisiko Kimia Daging Sapi Di Pasar Kota Malang. Jurnal Ilmu dan Teknologi Hasil Ternak, 8(2) Hal 18
Risnajati, D. 2010. Pengaruh Lama Penyimpanan dalam Lemari Es terhadap PH, Daya Ikat Air, dan Susut Masak Karkas Broiler yang Dikemas Plastik Polyethylen. Jurnal Ilmiah Ilmu-Ilmu Peternakan Mei, 8(6) hal: 309-315

Soeparno. 2005. Ilmu Dan Teknologi Daging. Edisi ke-4. Yogyakarta: Gadjah Mada University Press. 